\title{
Assessing The Extent of Land Use/Land Cover Change of Guga Forest Reserve, Giwa - Kaduna (1986-2019)
}

\author{
Aliyu Hassan Ibrahim \\ PhD, DEPARTMENT OF ENVIRONMENTAL SCIENCE, \\ FACULTY OF ENVIRONMENTAL STUDIES, \\ KADUNA POLYTECHNIC, \\ KADUNA, NIGERIA \\ DOI: 10.29322/IJSRP.10.11.2020.p10734 \\ http://dx.doi.org/10.29322/IJSRP.10.11.2020.p10734
}

\begin{abstract}
The relevance of forests to the environment and mankind cannot be overemphasized, as it is often referred to as an important component of the ecosystem at all levels which provides a wide range of services and functions such as; regulating water supplies, buffering floods and droughts, mitigating the adverse effects of Green House Gases (GHG) emission and harboring biodiversity. The aim of this research was to determine the extent of lanuse/landcover change of Guga Forest Reserve in, Shika, Giwa Local Government Area of Kaduna State, Nigeria. The methodology adopted for this research includes using Remote Sensing and Geographic Information (GIS) techniques, Landsat MSS imagery of 1986, Landsat TM imagery of 1990, Landsat ETM+ data of 1999 and Landsat 8 OLI image 2019. The datasets were processed and classified into land use/land cover classes using the supervised classification technique in Erdas imagine 9.2 environment and ArGIS 10.1. The result revealed that the result generated from 1986 LandSat MSS (Fig. 1) indicates that agricultural land occupied the highest proportion of the total land accounting for more than half of the entire area (51.4\%), followed closely by bare land $(29.2 \%)$ while forest, built-up and water body amounted to $13.9 \%, 4.7 \%$ and $0.8 \%$ respectively. The analysis further generated from Landsat 8 OLI (Fig. 4) revealed that agricultural land and built-up increased dramatically by $72.4 \%$ and $5.8 \%$ respectively. Forest, bare land and water body decreased to $9.9 \%, 11.8 \%$ and $0.1 \%$. This implies that agricultural land and built-up is fast encroaching into the forest land. The research concludes that there is high rate of urban encroachment in the Guga forest reserve area. There is also serious encroachment of physical development and cultivation on the forest cover, these could be attributed to unplanned urban growth and inadequate monitoring of the forest reserve. The study recommends that Proactive measure should be taken by all stakeholders in Giwa Local government area and Kaduna State towards a better understanding of the changing pattern of land-use and land-cover types of the area to be better equipped in order to manage various environmental challenges that might be associated with such changes.
\end{abstract}

Index Terms- Land Use; Land Cover; Change; Environment; Encroachment

\section{INTRODUCTION}

$\mathrm{U}$ rban concept varies from country to country and with periodic reclassification, can also vary within one country over time, making direct comparisons difficult. An urban area can be defined by an administrative criteria and political boundaries within the jurisdiction of a municipality or town committee. A threshold population size where the minimum for an urban settlement is 2,000 in habitat and this figure varies between 2000 and 50,000 people or where a significant majority of the population engaged in non-agricultural activities (Brenna, 1990; Abubakar, 2012; Danburi, 2014). Urban growth refers to the relative or absolute increase in the number of people who live in towns and cities (Mathew, 2010; Akingbogun, et. al., 2012; Albert, et. al., 2016). The pace of urban population growth depends on the natural increase of the urban population and the population gained by urban areas through both net rural-urban migration and the reclassification of rural settlements into cities and towns (Cohen, 2005). However, majority of the world's population today lives in urban areas thereby causing an unprecedented expansion of urban areas (United Nations, 2009; Cohen, 2016). Based on the United Nation's report in 2008, more than 50 percent of the world population presently lives in cities of varying sizes and this will continue to increase particularly in developing regions of the world (Adesina, 2005; Daramola and Ibem, 2010; United Nations, 2009; Danburi, 2014).

Globally, the towns and cities of developing countries are growing rapidly in both population and areal coverage, due to great waves of distress migration from rural areas. Thus, the urban centre in developing countries are expected to double their total population from 2 billion in 2000 to 4 billion by the year 2030, and triple their total built-up areas from about 200,000 square kilometres to more than 600,000 square kilometres within this same period, given an annual average density decrease of $1.7 \%$ to constitute $54.5 \%$ of the total urban built-up areas in the world by 2030 (Adesina, 2005; Shlomo, Stephen and Daniel, 2005; Cohen, 2016).

Expanding population has brought with them a range of problems for both the physical and built environment. As our big cities have grown away from the centre to accommodate people's settlement needs, suburbs have mushroomed outwards, producing what is referred to as 'urban sprawl (Danburi, 2014; Balogun, et. al., 2017). This process means that the natural environment suffers 
as more space is required for the construction of houses, roads, the development of industry among other. As more ecosystems are disrupted and habitats are destroyed, urban growth leads to an even greater reduction and distortion of biodiversity of proximal area (Skwirk, 2014; Danburi, 2014).

In the loss of biodiversity according to World Fact Book (2012), Nigeria was identified as one of the countries with the highest rate of forest loss (3.3 percent) in the world. Since 1990, the country has lost 6.1 million hectares or 35.7 percent of its forest covers. It also recorded that Nigerian most biodiversity ecosystem is fast depleting at an unbelievable rate. For example, between 1990 and 2005, Nigeria lost an average of 409,700 hectares of forest every year equal to an average deforestation rate of 2.38 percent. As of 2005 , Nigeria has the highest rate of deforestation in the world according to Food Agriculture Organization of the United Nations (FAO, 2010a; FAO, 2010b). The significant effect of loss of forest/vegetation is the exposure of bare surfaces to disaster such as erosion, pollution and consequently climatic change with an adverse effect on both physical and human environment (Sheyin, 2004; Jaiyeoba and Essoka, 2016).

However, the situation in Guga Forest Reserve, like any other forest globally, is of both economic and environmental consequences. However, due to rapid urban growth, coupled with poor monitoring strategy, this forest reserve is now threatened greatly which could be devastating if it is not properly managed. Human activities are recognized worldwide as the major cause of deforestation, with the agricultural and urban-industrial activity complex which is considered as important factors (Geist and Lambin, 2003; Vince and Iovanna, 2006; Abubakar, 2012; Danburi, 2014; Mathew, 2016). Hence the need to assess the effect of urban growth within the area especially as it affects the forest land.

\section{Application of Remote Sensing and GIS in Forest Studies}

Ati, Abbas, Sheyin and Mohammed (2010) used Remote Sensing and GIS in assessing changes in Kagoro Forest in Southern part of Kaduna State. The results of the analysis revealed that settlement and cultivated area increased between 1987 and 2005 by $72 \%$ and $17.77 \%$ respectively while undisturbed forest decreased by $24.06 \%$ within these same periods. The results show a significant depletion of the forest because of human activities particularly cultivation for agricultural purposes.

Abubakar, 2012 and Danburi, 2014 reviewed forest cover change in Jorhat Golaghat District of Assam using Remote sensing and GIS. They carried out a comparative study using toposheets of 1974 and IRS 1D LISS-3 bands 2, 3 and 4, imagery of 2005. The reserve forest areas were mapped from the satellite imagery using the visual interpretation techniques. The imagery was visually interpreted using six basic photo elements viz. tone, texture, shape, size, pattern and association together with numerous ground truth observations. With these assemblages of photo elements showed against each terrain unit, boundaries of distinct reserve forest were demarcated. The results showed substantial decrease in the Reserve Forest Area. Dayang Reserve forest is totally vanished by encroachment, same was the condition of Nambar, Holongapar and Disai Valley Reserve Forest where the crown coverage is less than 40 percent of the total Reserve
Forest Area. The analysis reveals that the total reserves forest area decreased tremendously from $458.8 \mathrm{sq} \mathrm{km}$ in 1974 to $176.68 \mathrm{sq} \mathrm{km}$ in 2005 .

Daniel and Ayobami (2007) assessed changes in land use land cover in some part of southwestern Nigeria over 16 years. Satellite imageries of 1986 and 2002 were used. The result showed that the disturbed/degraded forest constitute the most extensive type of land use land cover in the study area. The increasing population and economic activities were noted to be putting pressure on the available land resources. It was also discovered that $98.3 \%$ and $63.7 \%$ of the area covered with high forest in Ikeji forest reserve and Akure forest reserve respectively were converted to shrub lands / farm lands over the period of 16 years.

Jibril (2009) assessed changes in vegetation cover in Kpashimi forest reserve in Niger state Nigeria. Landsat TM, ETM plus, SPOT and Nigeria- Sat 1 of 1987, 1994, 2004 and 2007 were used. The images were classified using Maximum Likelihood classification algorithm by the extraction of Normalized Differential Vegetation Index based on supervised classification. Post classification method was applied. Arc GIS 9.2 and Erdas Imagine 8.3 image processing software were used in calculation the landscape indices and the quantification of landscape transformation processes. The spatial pattern change revealed that the landscape structure of the forest reserve has change tremendously due to shrinking in the proportion of the savannah woodland and Riparian forest (Jimoh, 2011; Daniel and Ayobami, 2017).

\section{THE STUDY AREA AND RESEARCH METHODOLOGY}

\section{Location}

Historical Development: The history of Shika can be traced to the historic development of makayo village. The emergence of shika no dout, came in as a result of the expansion and growth of makayo village which was as far back as 1907. This expansion was mainly due to the establishment of some Institutions and Industries such as, the National Animal Research Institute (NAPRI), Ahmadu Bello University Teaching Hospital (ABUTH), Champion Soap Factory, Shika Ranch, Shika Grains Processing Center among others. The relocation of ABUTH to its present permanent site in the year 2005 saw a rapid development of Shika and its environs. Shika no doubt, came into being due to the influx of workers from various areas to the institution (ABUTH). Thus, most of the workers coming from afar settled at Shika town. Hence, the need for accommodation was inevitable. Therefore, this experience brought about rapid increase in human population (Abubakar, 2012; Danburi, 2014). Guga Forest Reserve is situated 12.9 kilometer ( 8 miles) west of Samaru along Zaria Funtua road in Giwa Local Government Area of Kaduna State, with an aerial extent of 4634 hectares. It is located on the plain of the northern part of Kaduna State. The forest reserve lies between Latitudes $1110^{\text {ee }} 00 \mathrm{~N}$ and $1116^{\text {ee }} 14 \mathrm{~N}$ of the equator and Longitudes $730^{\text {ee }} 34$ " E and $737^{\circ e} 06$ " E of the Greenwich meridian. It has a total land area of about 2,066 square kilometers. It is bounded to the north by Funtua, east by Sabon gari, Zaria and 
Kudan, in the south; it is bounded by Igabi local government area as shown in Fig. 1 and 2.

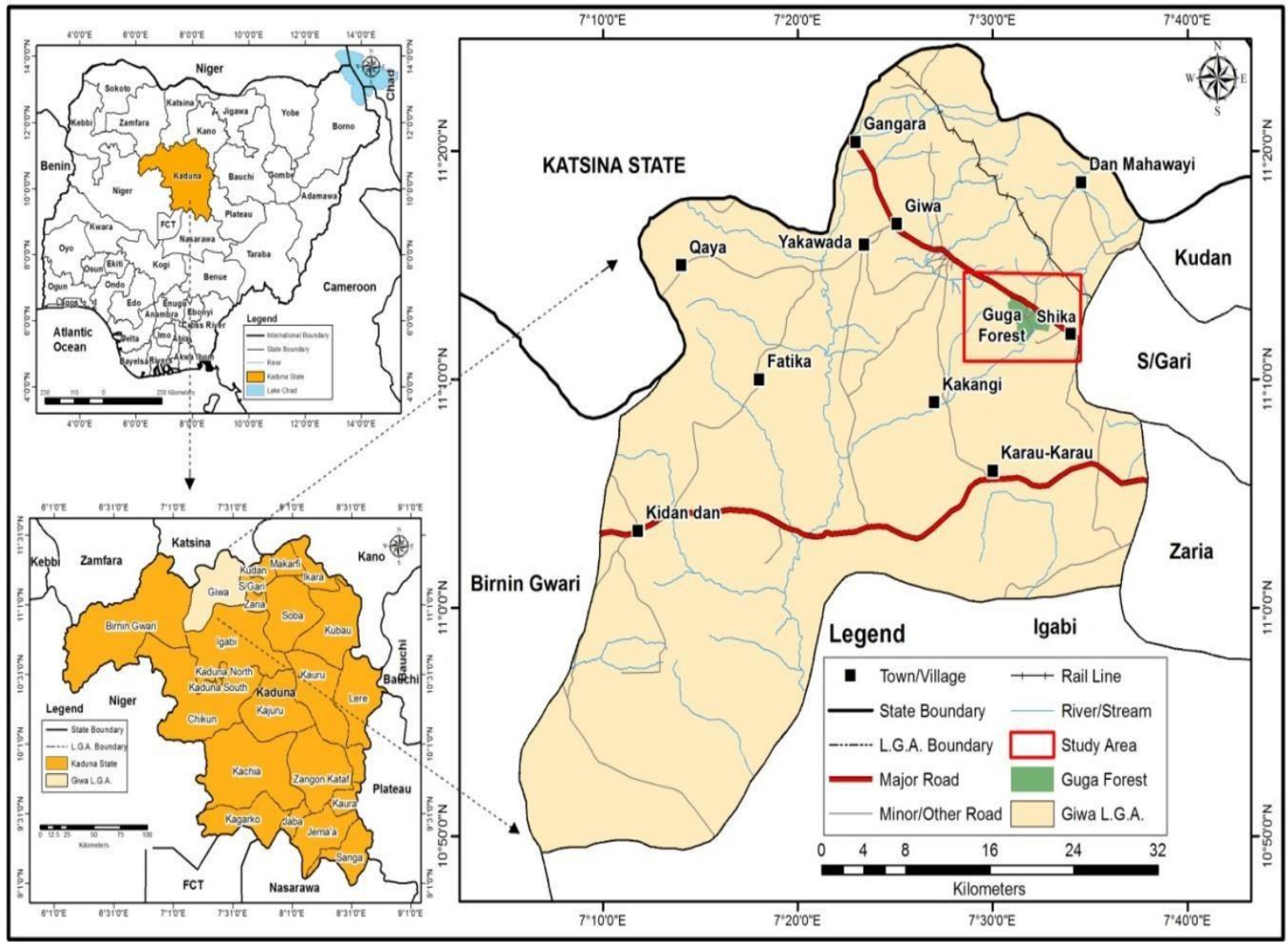

Figure 1: Giwa Local Government Area.

Source: KADGIS, Kaduna State, 2020

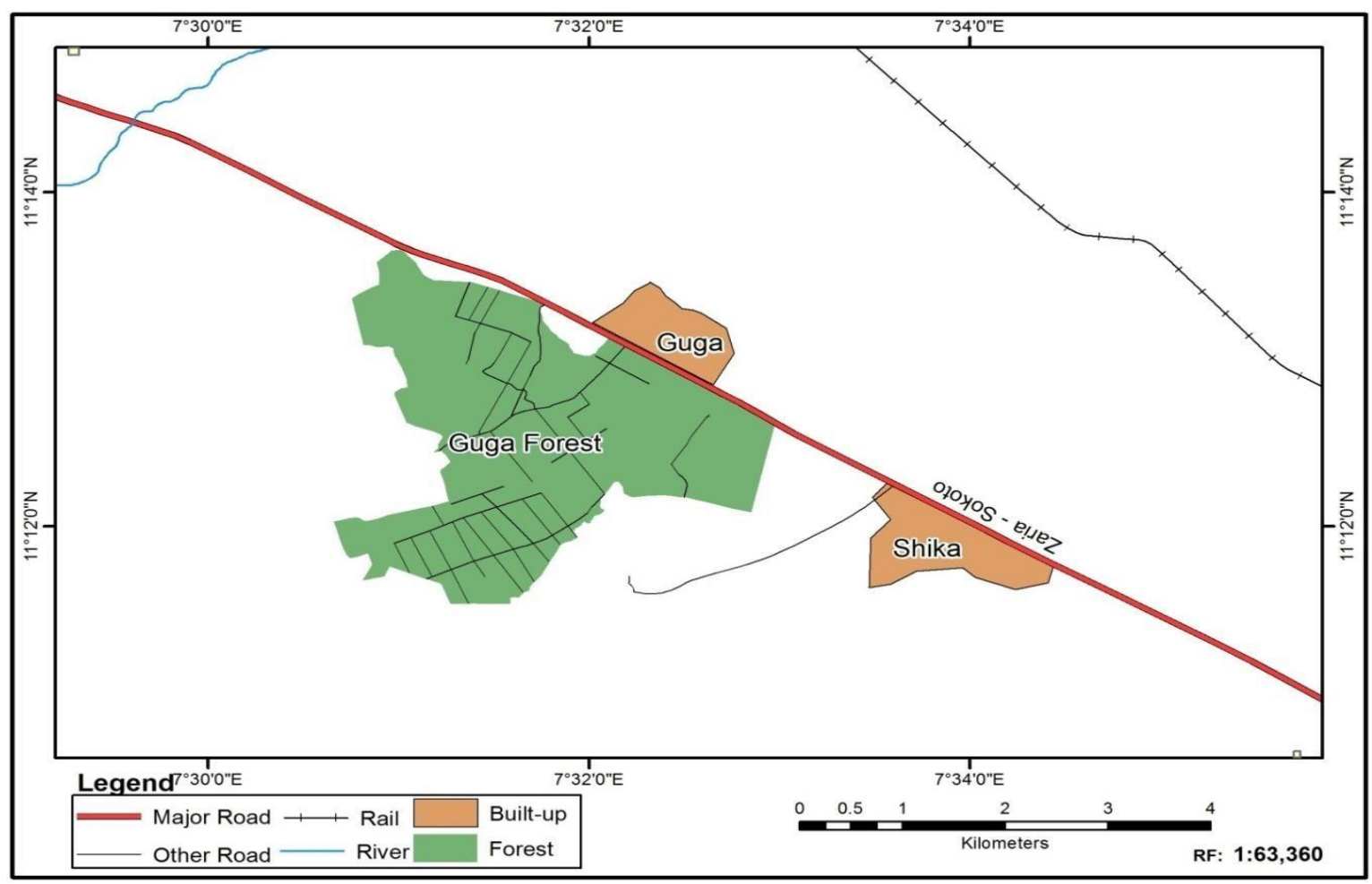

Figure 2: Map of Giwa LGA 
Source: KADGIS, Kaduna State, 2020

\section{Land Use/Land Cover Change of The Area for The Period 1986-2019}

The Land use/land cover change of the area was determined through broadly classifying the images into five different categories/polygons viz: built-up, forest land, water bodies, agricultural land and bare land. After the image classification, the histogram (image statistics) of the area coverage (extent) of each land use land cover theme for each period of study were used to determine the land use land cover change by comparing the statistics of the recent image with that of the previous date (Abubakar, 2012; Agam, 2014; Danburi, 2014). The change in square kilometers of a land use/ land cover type was derived by subtracting the previous area coverage $\left(\mathrm{km}^{2}\right)$ from the recent. Change in square kilometers $=$ the previous area coverage of land use/land cover type of interest minus the recent (for instance, the area coverage of built- up in 1986 minus the area coverage of builtup in 1990). To get the percentage change of each land use/land cover type, this formula was used:

Observed Changes $\mathrm{KM}^{2}$ x $100 \%$

Percentage change of class $=$

Base-year

\section{CHARACTERIZATION OF LAND-USE/LAND- COVER OF THE AREA}

The land-use/land-cover classes of Guga Forest in 1986, 1990, 1999 and 2019 were characterized into five prominent classes which include: Built-up, Agricultural land, Forest land, Bare land and Water bodies as shown in Fig. 3, 4, 5, 6 and Table 1 below.

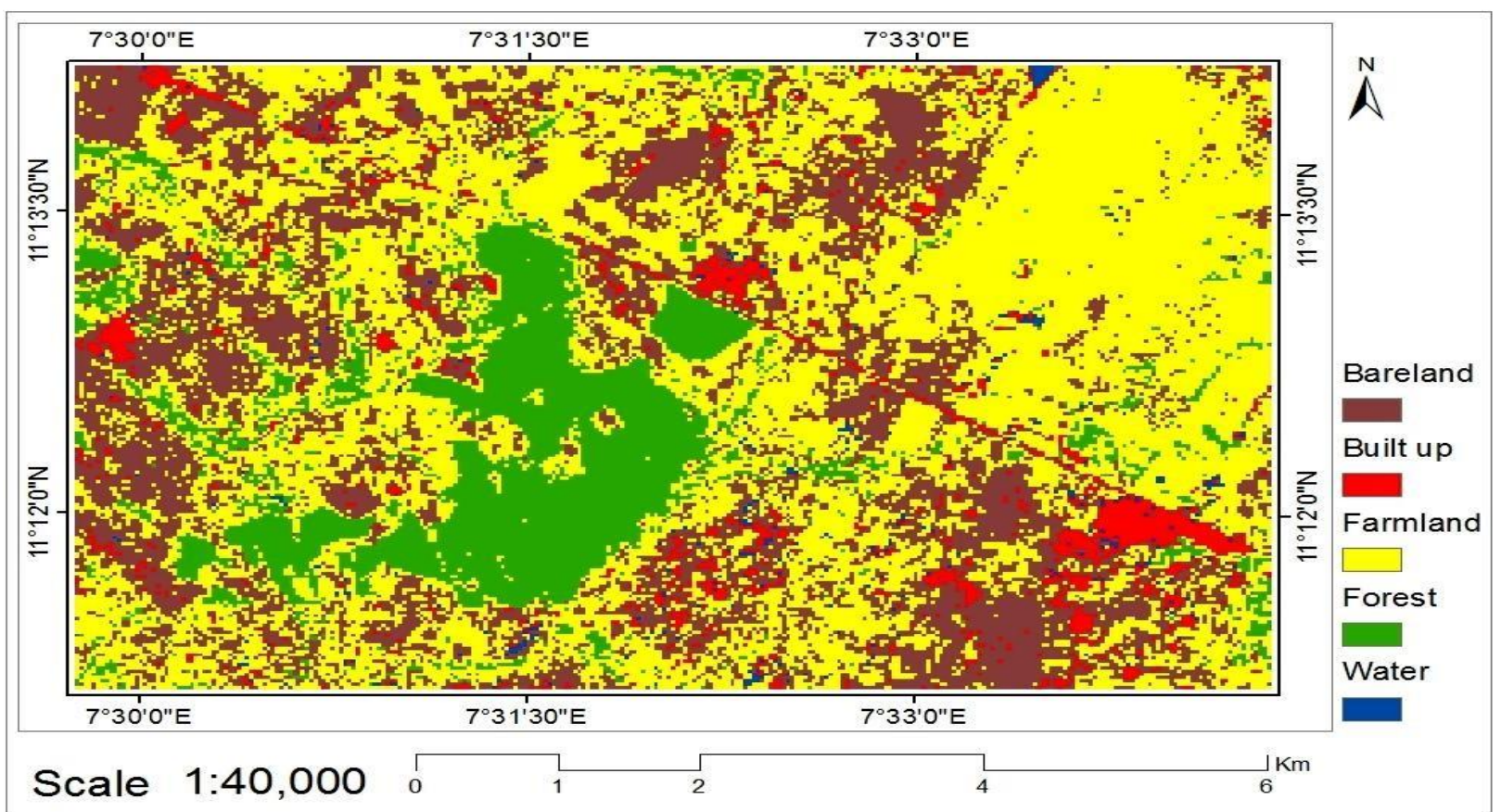

Fig 3: 1986 Land use/Land cover Map of the Study Area Source: Field Survey, 2020 


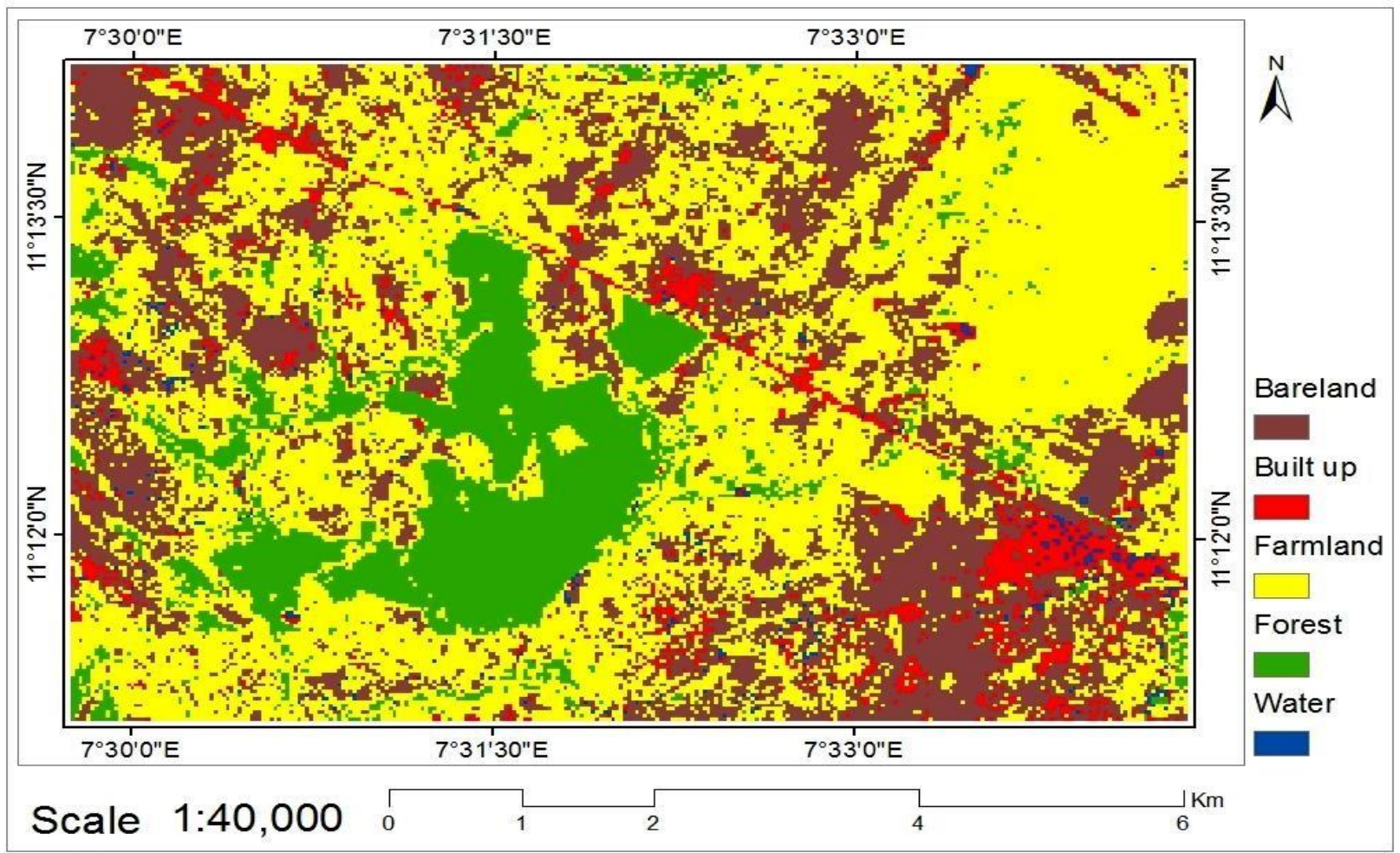

Fig. 4: 1990 Land use/Land cover Map of the Study Area Source: Field Survey, 2020

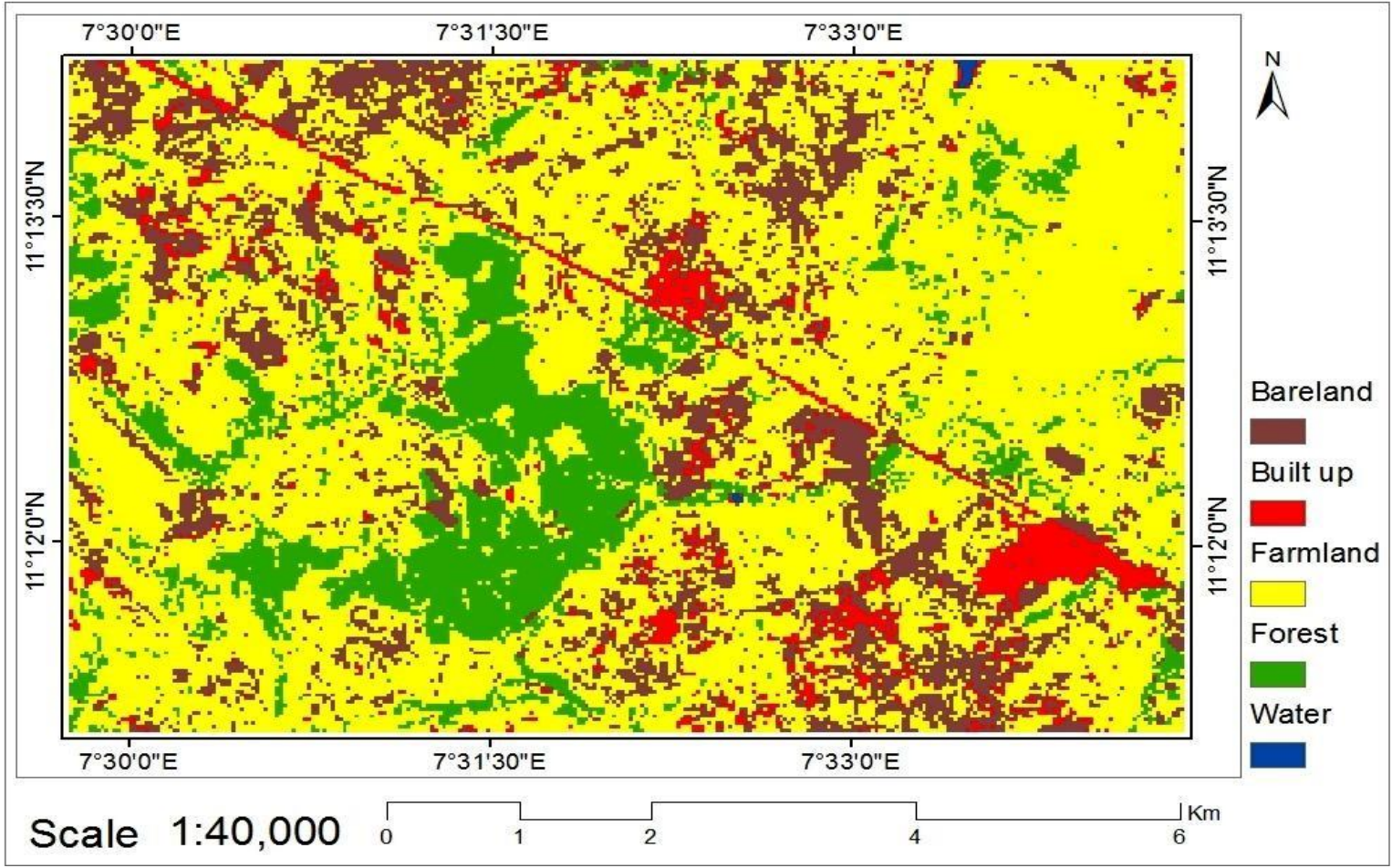

Fig 5: 1999 Land use/Land cover Map of the Study Area Source: Field Survey, 2020 


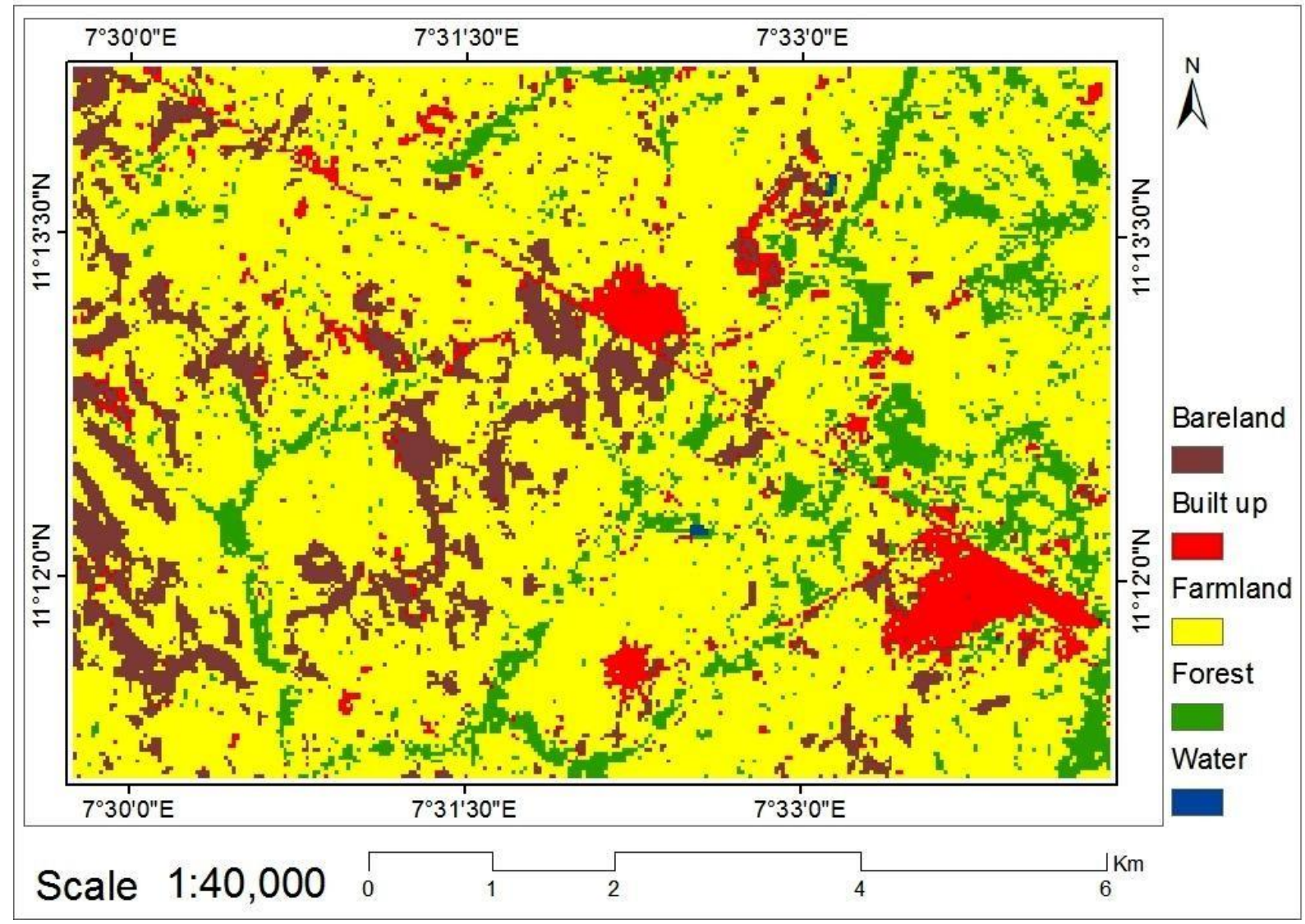

Fig 6: 2019 Land use/Land cover Map of the Study Area

Source: Field Survey, 2020

Table 1: Extent and Proportion of Land-use/cover in 1986- 2019

\begin{tabular}{llllllllll}
\hline & $\mathbf{1 9 8 6}$ & $\mathbf{1 9 9 0}$ & $\mathbf{1 9 9 9}$ & $\mathbf{2 0 1 9}$ & & & & \\
\hline Land use & $\mathrm{Ha}$ & $\%$ & $\mathrm{Ha}$ & $\%$ & $\mathrm{Ha}$ & $\%$ & $\mathrm{Ha}$ & $\%$ \\
Bare land & 1409.0 & 29.2 & 1339.9 & 27.7 & 851.0 & 17.6 & 570.1 & 11.8 \\
& & & & & & & & \\
Built up & 224.8 & 4.7 & 240.5 & 5.0 & 260.1 & 5.4 & 279.5 & 5.8 \\
Agric/land & 2483.0 & 51.4 & 2538.1 & 52.5 & 3062.9 & 63.4 & 3498.4 & 72.4 \\
& & & & & & & & \\
Forest & 673.1 & 13.9 & 665.3 & 13.8 & 653.3 & 13.5 & 479.1 & 9.9 \\
Water & 40.4 & 0.8 & 46.6 & 1.0 & 3.2 & 0.1 & 3.2 & 0.1 \\
\hline Total & $\mathbf{4 8 3 0 . 4}$ & $\mathbf{1 0 0 . 0}$ & $\mathbf{4 8 3 0 . 4}$ & $\mathbf{1 0 0 . 0}$ & $\mathbf{4 8 3 0 . 4}$ & $\mathbf{1 0 0 . 0}$ & $\mathbf{4 8 3 0 . 4}$ & $\mathbf{1 0 0 . 0}$ \\
\hline
\end{tabular}

Source: Author's Analysis, 2020

The Land-use/Land-cover maps for the four years of the study depicting the five Landuse/land-cover classes were generated and presented in Fig. 3, 4, 5 and 6. The area and percentage coverage of each of the class is further depicted in Table 1.

From the analysis, Table 1 shows the various land cover types and the proportion of the total area occupied by each of them. The result generated from 1986 LandSat MSS (Fig. 3) indicates that agricultural land occupied the highest proportion of the total land accounting for more than half of the entire area (51.4\%), followed closely by bare land $(29.2 \%)$ while forest, built-up and water body amounted to $13.9 \%, 4.7 \%$ and $0.8 \%$ respectively.

The image classification resulted from 1990 LandSat TM (Fig 4), shows that agricultural land remains the major land use land cover with an increase to $52.5 \%$, Bare land and forest has decreased to $27.8 \%$ and $13.8 \%$ while built-up and water body increased slightly by $5.0 \%$ and $1.0 \%$.

Results generated from LandSat ETM 1999 (Fig 5) still recorded an increase in the proportion of agricultural land (63.4\%) and built-up areas $(5.4 \%)$ while forest, bare land and water body still experienced a tremendous decline by $13.5 \%, 17.1 \%$ and 
$13.5 \%$ within that same study period. The analysis further generated from Landsat 8 OLI (Fig 6) revealed that agricultural land and built-up increased dramatically by $72.4 \%$ and $5.8 \%$ respectively. Forest, bare land and water body decreased to $9.9 \%$, $11.8 \%$ and $0.1 \%$. This implies that agricultural land and built-up is fast encroaching into the forest land. The increase in built-up as well as agricultural land was as a result of increase in human population which is presumably due to both migration and natural increase which has given rise to higher demands for agricultural land as well as physical development like residential, commercial, infrastructural and other urban structure. In the quest to meet up with these demands, some of the forest/vegetation land in the area was replaced by these land use classes.

The pressure on the land as a result of increase in the demand of land together with inadequate planning led to the encroachment of built-up and agricultural land on the other area occupied by forest and other land cover types irrespective of the consequences. The dramatic increase in conversion of land for physical development and agricultural activities led to decrease in bare land and water bodies. However, bare surfaces could be seen in built-up area as paved or unpaved land during construction; in cultivated lands during cultivation or after harvesting; along river course as deposition; in forests due to clearing as well as along or on roads mostly when it is unpaved.

\section{Land-use/Land-cover change}

The result of land-use/land-cover change of the study area between 1986-1990, 1990-1999, 1999-2019, and 1986-2019 is presented in Table 2.

Table 2: Extent of Land-use/Land-cover change

\begin{tabular}{|c|c|c|c|c|c|c|c|c|}
\hline \multicolumn{2}{|c|}{$1986-1990$} & \multicolumn{2}{|c|}{$1990-1999$} & \multirow{2}{*}{$\frac{1999-2014}{\%}$} & \multicolumn{2}{|c|}{$1986-2019$} & \multirow[b]{2}{*}{$\mathrm{Ha}$} & \multirow[b]{2}{*}{$\%$} \\
\hline Land use & $\mathrm{Ha}$ & $\%$ & $\mathrm{Ha}$ & & $\mathrm{Ha}$ & $\%$ & & \\
\hline Bare land & -69.1 & -4.9 & -489.0 & -36.5 & -280.8 & -33.0 & -838.9 & -59.5 \\
\hline Built up & 15.7 & 7.0 & 19.6 & 8.2 & 19.4 & 7.5 & 54.7 & 24.3 \\
\hline Agric/land & 55.1 & 2.2 & 524.8 & 20.7 & 435.5 & 14.2 & 1015.4 & 40.9 \\
\hline Forest & -7.8 & -1.2 & -12.0 & -1.8 & -174.2 & -26.7 & -194.0 & -28.8 \\
\hline Water & 6.2 & 15.4 & -43.5 & -93.2 & 0.1 & 2.9 & -37.2 & -92.0 \\
\hline
\end{tabular}

Source: Field Survey, 2020

Table 2 revealed the extent of change of change in the land use/ land cover in the study area. In 1986 to 1990 forest, bare land and water body decreased by $-1.2 \%,-4.9 \%$ and $-43.5 \%$ respectively. Built-up and agricultural land which is an attribute of urban growth increased by $7.0 \%$ and $2.2 \%$. Similarly, from 1990 to 1999 , built-up increased by $8.2 \%$, agricultural land by $20.7 \%$, water body by $31.2 \%$ while forest and bare land experienced a negative change by $-1.8 \%$ and $-36.5 \%$. This may be due to the creation of a Giwa Local Government Area in 1991. More so, in 1999 to 2019, built-up, agricultural land and water body increased drastically by $7.5 \%, 14.2 \%$ and $2.9 \%$ while forest bare land decreased by $-26.7 \%$ and $-33.0 \%$.

Lastly, the extent of the change in land use/land cover between 1986- 2019 revealed that, built-up and agricultural land increased drastically by $24.3 \%, 40.9 \%$ within the 28 years study period. On the other hand, forest reduced by $-28.8 \%$, bare land by
$-59.5 \%$ and water body -92.0 The result showed a clear indication that physical development has taken over. The increase in physical development coupled with inadequate monitoring of the forest reserve led to the encroachment.

The sharp increase was attributed to the development in transport network, presence of some basic amenities, primary health care as well as the movement of Ahmadu Bello University Teaching Hospital (ABUTH) from Kaduna, Tudun-wada and Malumfashi to its present permanent site in 2005. These act as a pull factor by creating employment and commercial activities in the area. These trigger the increased in population as well as physical development. The increasing urbanization resulted in the removal of forest cover in the area mostly for the purpose of construction, cultivation, cooking energy and electric poles. The increasing urbanization has also led to a higher demand for available land in the area as seen in Figs. 7 below which shows the chart of the classified land use/cover change. 


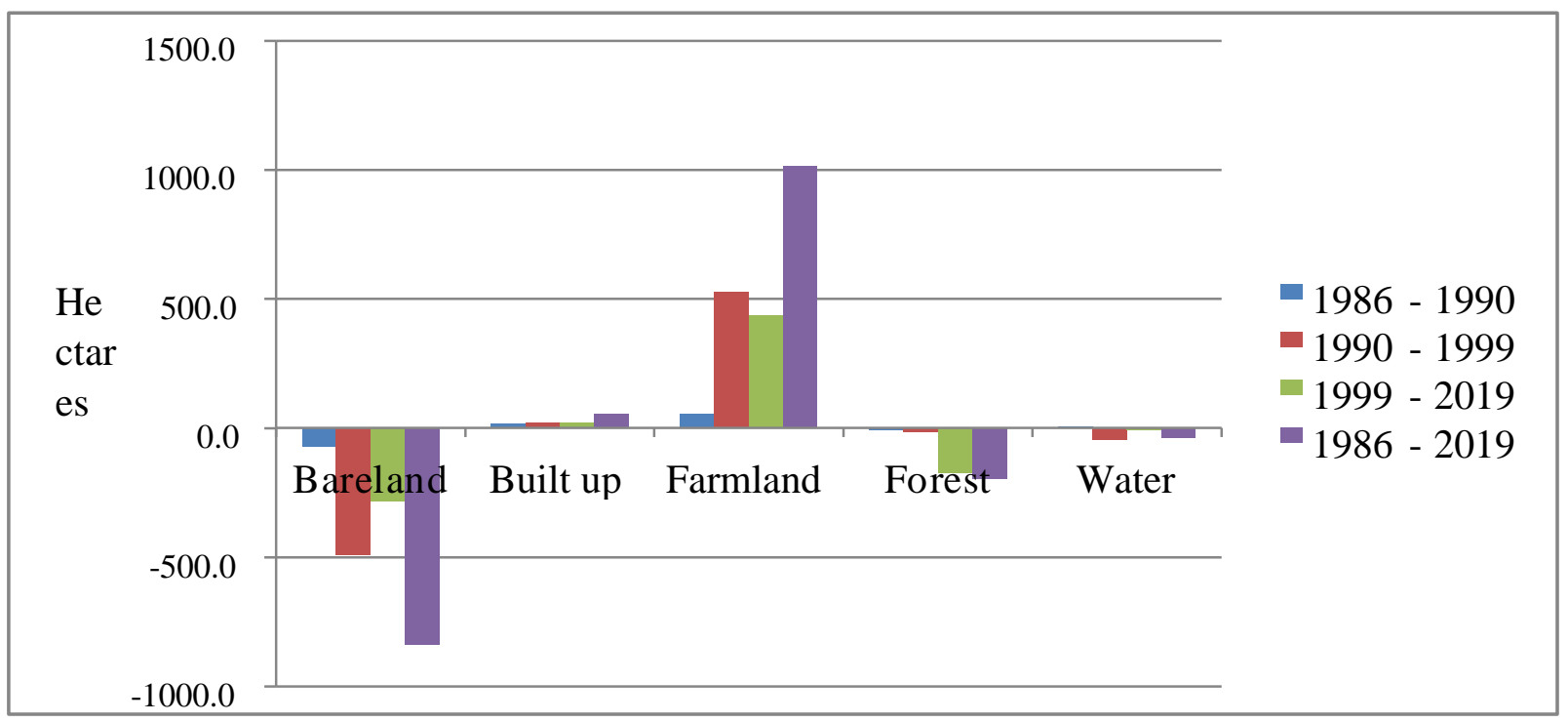

Fig: 7: Land use/Land cover Change

Source: Field Survey, 2020

From the analysis, it was observed that built-up and agricultural land witnessed a significant change at the expense of the forest. Under a high population pressure, it is therefore natural to expect some expansion in cultivated land as it reflects land exhaustion such that no much uncultivated land was available, a consequence of these is much; pressure must be applied to the already existing cultivated land into more intensification of farming activities.

Furthermore, this significant reduction in other land use/ land cover types could be attributed partly to urban expansion or population growth as well as increased in agricultural activities especially within and around the forest as seen in Fig 4 to meet with the growing demands of the growing population in the area.

The study provided an insight on the effect of urban encroachment on Guga forest reserve in Giwa Local Government Area of Kaduna State. The finding of this research revealed evidence of gradual urban expansion over the study period as the land cover had percentage coverage of $4.7 \%$ in $1986,5.0 \%$ in $1990,5.4 \%$ in 1999 and $5.08 \%$ in 2019.The built-up area and agricultural land have shown a continuous increased within the period of study while forest/vegetation and bare land declined. However, the analysis revealed that builtup and agricultural land has eating up the forest land, most part of the study area is still rural as most people within the study area still engage in agricultural activities. The period 1986-1990 recorded the highest annual growth (1.7\%) while the average annual growth rate within the study period (1986 - 2019) was $0.9 \%$. Unplanned expansion has led to conversion of forest and bare land into physical development. The highest proportion of forest loss was noticed between 1990 - 1999 with an annual rate of $0.2 \%$, within this same study period, about 19.6 hectares of land which amounted to about $8.2 \%$ was added to builtup land.

\section{CONCLUSION}

This study reveals high rate of urban encroachment in the Guga forest reserve area. There is serious encroachment of physical development and cultivation on the forest cover. These could be attributed to unplanned urban growth and inadequate monitoring of the forest reserve. If this situation continues at this rate, the vegetation cover in the area would soon be lost to the detriment of the environment. A cursory observation on Guga Forest reveals that a section of the forest has been degraded through activities like fuel wood harvesting, timber logging, agricultural activities, animal grazing, bush burning and rapid urban growth. These changes if unchecked, in the long run can create serious environmental problems like soil erosion, sedimentation of river channels, loss of soil productive capacity, loss of biodiversity.

\section{RECOMMENDATIONS}

Based on the identified changing nature and rate of various land-use/land-cover types identified in the study area especially from 1986 to 2019, the following are recommended:

- Proactive measure should be taken by all stakeholders in Giwa Local government area and Kaduna State towards a better understanding of the changing pattern of land-use and land-cover types of the area to be better equipped in order to manage various environmental challenges that might be associated with such changes.

- The management of Guga forest reserve should adopt Remote Sensing and Geographic Information System (GIS) techniques which have proved to be efficient in the monitoring of vegetation cover. This would help to control encroachment and illegal logging in the area.

- Afforestation and reforestation should be encouraged and adopted by the Ministry of Environment and Natural Resources in the State especially around the study areas 
in order to resuscitate lands that are devoid of vegetal cover.

\section{REFERENCES}

[1] Abubakar, S. (2012). The Impact of Rural Infrastructure on Social Development in Giwa Local Government Area of Kaduna State, Nigeria: An Unpublished MSc Thesis Department of Geography, Ahmadu Bello University. Zaria.

[2] Adesina, F. A. (2005). Geoinformation and Natural Resource Exploitation in African; United Administration and Development in Nigeria, In: E.A. Olofin and Patrick, S. (eds), AMBIO. A Journal of Humanity Environment. 30(1):67-69.

[3] Akingbogun, A. A., Kosoko, O. S. and Aborisade, D. O. (2012). Remote Sensing and GIS Application for Forest Reserve Degradation, Prediction and Monitoring. In: FIG Young Surveyors Conference, Knowing to Create the Future, Rome, Italy, 4th-5th May.

[4] Albert, O., Edmund, C. M. and Yaw, A. T. (2016). Use of Remote Sensing and GIS Techniques as a Decision Tool in Land Administration: The Case Study of Lagos, Nigeria. Promoting Land Administration and Good Governance. Journal of 5th FIG Regional Conference, Accra, Ghana.

[5] Ati, O. F., Sheyin, T., Abbas, I. and Mohammed, S. O. (2010). Assessing the Changes in Kagoro Forest, Kaduna State Nigeria, Using Remote Sensing and GIS. Research Journal of Applied Sciences, Engineering and Technology 2(2):121-132.

[6] Balogun, I. A, Debo, Z. A., Ahmed, A. B. and Tobi, E. M. (2017). Analysis of Urban Expansion and Land use changes in Akure, Nigeria. Using Remote Sensing and Geographic Information System (GIS) Techniques. Journal of Geography and Planning. 4(9): 533-541.

[7] Brenna, E. M. (1999). Population, Urbanization, Environment and Security: A Summary of the Issues. Washington, D .C.; Woodrow Wilson International Centre for Scholars. Comparative Urban Studies Series, 22.

[8] Cohen, B. (2016). Urbanization in Developing Countries: Current Trends, Future Projections, and Key Challenges for Sustainability. Technology in Society, 28: 63- 80

[9] Danburi, C. N. (2014). The Effect of Urban Encroachment on Guga Forest Reserve in Giwa Local Government Area, Kaduna State, Nigeria. An Unpublished MSc Thesis submitted to the Department of Geography, Ahmadu Bello University, Zaria - Kaduna State

[10] Daniel, A. M. and Ayobami, T. S. (2017). Applications of Remote Sensing and GIS in Land use/Land cover Mapping and Change Detection in part of South Western Nigeria. African Journal of Environmental Science and Technology, 1(5): 99-107.

[11] Daramola, A. and Ibem, E. (2010). Urban Environmental Problems in Nigeria; Implications for Sustainable Development. Journal of Sustainable Development in Africa. 12(1):18-20.

[12] FAO (2010a). Global Forest Resources Assessment, Terms and Definition. Forest Department.
[13] FAO (2010b). Global Forest Resource Assessment, Main report. FAO $\begin{array}{llll}\text { Forestry Paper } & \text { No } & \end{array}$ www.fao.org/docrep/o13/i1757e/i1757e00.htm.

[14] Geist, H. and Lambin, E. (2004). Is Poverty the Cause of Deforestation? The International Forestry Review 5(1): 64-67.

[15] Jaiyeoba, I. A. and Essoka, P. E. (2016). Soil and Vegetation in: The Middle Niger River: A field course hand book. Department of Geography, Ahmadu Bello University, Zaria.

[16] Jibril, A. (2009). Assessment of the Pattern of Changes in Vegetation Cover of Kpashimi Forest Reserve in Niger State, Nigeria: An Unpublished M.sc Thesis Department of Geography, Ahmadu Bello University. Zaria.

[17] Jimoh, S. C. (2011). Mangrove Degradation in the Coastal Southeast of Nigeria: Causes, Effects and Remedies for the Future, In Popoola, L. Abu, J.E. and Oni, P.I. (eds.), Forestry and National Development. FAN Publication, Ibadan, pp. 17-38

[18] Mathew, G. T. (2016). Urban Growth Monitoring of Birmingham, Using Landsat MSS and TM Imagery. An Unpublished M.Sc. Thesis, Department of Geography, University of Alabama.

[19] Sheyin, N. T. (2008). The Use of GIS and Remote Sensing in Assessing Land Cover Changes in the Kagoro Forest. An Undergraduate Project, Department of Geography, Ahmadu Bello University, Zaria.

[20] Sheyin, G. A. (2004). The Nature of Deforestation in Tukur- Tukur District, Zaria. An Undergraduate Project, Department of Geography, Ahmadu, Bello University, Zaria.

[21] Shlomo, A., Stephen, C. S. and Daniel, L. C. (2005). The Dynamics of Global Urban Expansion. The World Bank. Washington D.C.

[22] Skwirk, B. (2014). Urban Growth and Decline: Issues in Australia Environment. Red Apple Educational Ltd.

[23] United Nations (2009). World Urbanization Prospects; the 1996 Revision, New York; United Nation.

[24] Vince, C. and Iovanna, R. (2006). Analyzing Spatial Hierarchies in Remotely Sensed Data: Insights from a Multilevel Model of Tropical Deforestation. Land use policy (23)3, 223-238.

[25] WorldFactBook www.cia.gov/library/publication/theworldfactbook/fields/2212.htm1. Retrieved on 20th May, 2020.

\section{AUTHORS}

First Author - ALIYU HASSAN IBRAHIM, PhD

aliyuibrahim@kadunapolytechnic.edu.ng

DEPARTMENT OF ENVIRONMENTAL SCIENCE, FACULTY OF ENVIRONMENTAL STUDIES, KADUNA POLYTECHNIC, KADUNA, NIGERIA 